\title{
Filhos da (in)justiça
}

\author{
DOI: $10.15175 / 1984-2503-202113306$
}

\section{Luciana Simas*}

\begin{abstract}
Resumo
Este artigo apresenta falas de gestantes ou lactantes que passaram por audiências de custódia e responderam ao processo criminal em liberdade, ilustrando respostas institucionais acerca do pré-natal, parto e cuidados pós-parto fora do ambiente prisional. O objetivo foi documentar as possibilidades e dificuldades da aplicação de medidas desencarceradoras, a partir das narrativas de vivências das próprias mulheres. A pesquisa qualitativa baseou-se em análise de conteúdo, organizada a partir de modalidades temáticas com exploração do material coletado em entrevistas e diário de campo. Foram problematizados alguns obstáculos enfrentados na pesquisa empírica, bem como experiências das mulheres dentro e fora das prisões, referentes ao exercício da maternidade, convivência com o filho, desassistência estatal e consequências do aprisionamento. O relato das mães que obtiveram liberdade provisória ou prisão domiciliar em função da gestação demonstra realização adequada do pré-natal e desenvolvimento saudável das crianças, embora ainda sejam constatadas dificuldades durante o parto. A adoção de medidas desencarceradoras permitiu melhor acesso à saúde, contribuindo para a efetivação do direito humano à maternidade. A satisfação de poder cuidar dos seus filhos e conviver com a família foi constatada como um fator positivo determinante. Todavia, persistem situações de violência institucional, diante da insuficiência ou ausência de proteção estatal.
\end{abstract}

Palavras-chave: Mulheres; maternidade; prisões; prisão domiciliar; audiência de custódia.

\section{Hijos de la (in)justicia}

\section{Resumen}

Este artículo presenta declaraciones de mujeres embarazadas o en período de lactancia que fueron sometidas a audiencias de prisión provisional y respondieron al proceso penal en libertad, ilustrando respuestas institucionales relativas a la fase prenatal, el parto y de posparto fuera del ámbito carcelario. El objetivo fue documentar las posibilidades y dificultades de la aplicación de medidas de excarcelación a partir de los relatos de las propias experiencias de las mujeres. La investigación cualitativa se basó en el análisis de contenidos, organizado a partir de modalidades temáticas con el estudio de material recogido en entrevistas y diario de campo. Se analizaron algunos obstáculos encontrados en la investigación empírica, así como las vivencias de las mujeres dentro y fuera de las prisiones relativas al ejercicio de la maternidad, la convivencia con el hijo, la falta de asistencia estatal y las consecuencias del encarcelamiento. El informe de las madres que fueron puestas en libertad bajo fianza o arresto domiciliario como consecuencia de su embarazo demuestra una atención prenatal adecuada y un desarrollo saludable de los niños, aunque aún se observan dificultades en lo que respecta al momento del parto. La adopción de medidas de excarcelación permitió un mejor acceso a la salud, contribuyendo a la realización del derecho humano a la maternidad. La

\footnotetext{
* Doutora em Bioética, Ética Aplicada e Saúde Coletiva pela Universidade Federal do Rio de Janeiro, com intercâmbio na Universidade da Flórida - Levin College of Law. Mestre em Direito e Sociologia pela Universidade Federal Fluminense, integrante do Grupo de Pesquisa Saúde nas Prisões (ENSP/FIOCRUZ) e do LIDHS Laboratório Interdisciplinar de Direitos Humanos e Saúde (IESC/UFRJ). E-mail: lucianasimas06@gmail.com. http://lattes.cnpq.br/2633245603364166. 는 https://orcid.org/0000-0003-2494-8747
} 
satisfacción de poder cuidar de sus hijos y vivir con la familia resultó ser un factor determinante positivo. Sin embargo, persisten situaciones de violencia institucional, dada la insuficiencia o ausencia de protección estatal.

Palabras clave: Mujeres; maternidad; cárceles; arresto domiciliario; audiencia de prisión provisional.

\title{
Sons of (in)justice
}

\begin{abstract}
The following article presents statements by pregnant or breastfeeding women to have been through custody hearings and criminal proceedings while released on bail, illustrating institutional responses to prenatal, childbirth, and post-natal care outside the prison environment. The aim was to document the possibilities for and difficulties of applying release measures, according to the women's own narratives of violence. The qualitative research is based on an analysis of content and is organized according to thematic modules with an exploration of the material collected in interviews and field data. Several obstacles faced in the empirical study have been highlighted, as have the experiences of the women inside and outside the prisons, in terms of the exercise of motherhood, life with the child, the lack of state assistance, and the consequences of the imprisonment. The report from mothers to have been released on bail or placed under house arrest due to pregnancy demonstrates adequate pre-natal care and the children's healthy development, although difficulties were still experienced during childbirth. The adoption of measures to release the women allowed for better access to healthcare, in line with the human right to safe motherhood. The satisfaction of being able to care for their children and live alongside family stood out as a positive factor. Situations of institutional violence still persist, given the insufficiency or absence of state protection.
\end{abstract}

Keywords: Women; motherhood; prisons; house arrest; custody hearing.

\section{Enfants de l'(in)justice}

\section{Résumé}

Cet article présente les propos de femmes enceintes ou allaitantes ayant fait l'expérience d'audiences afférentes à leur détention provisoire et qui ont finalement attendu leur procès pénal en liberté, illustrant ainsi les réponses institutionnelles à la question des soins prénatals, de l'accouchement et des soins postnatals en dehors de l'environnement carcéral. L'objectif est ici de documenter les possibilités et les difficultés d'application de mesures de liberté conditionnelle à partir des récits de l'expérience des femmes concernées. La recherche qualitative s'est basée sur une analyse de contenu organisée à partir de modalités thématiques et de l'exploitation des données collectées lors des entretiens et dans le journal de terrain. Nous avons mis en perspective certains obstacles rencontrés lors de la recherche empirique, ainsi que les expériences des femmes à l'intérieur et à l'extérieur des prisons en ce qui concerne l'exercice de la maternité, la vie quotidienne avec l'enfant, l'absence d'assistance publique et les conséquences de l'incarcération. Le témoignage des mères qui ont obtenu la liberté provisoire ou l'assignation à résidence en raison de leur gestation ont montré la réalisation appropriée des examens prénatals et un développement sain des enfants, même si certaines difficultés sont encore constatées lors de l'accouchement. L'adoption d'alternatives à l'incarcération a permis un meilleur accès à la santé et contribué à la mise en œuvre effective du droit humain à la maternité. La satisfaction de pouvoir s'occuper de ses enfants et vivre auprès de sa famille constitue ainsi un facteur positif déterminant. Subsistent néanmoins des situations de violence institutionnelle face à l'insuffisance ou à l'absence de la protection de l'État.

Mots-clés : Femmes ; maternité ; prisons ; assignation à résidence ; audience de détention provisoire. 


\title{
(不) 正义的孩子
}

\section{摘要}

本文研究了处于怀孕或哺乳期女犯人的陈述，她们经历了收监听证会并获得监外限制自由的方式面对刑事诉讼的 权利。她们在监外享有公立医疗机构提供的产前准备，分娩和产后护理的社会福利。本文的目的是，根据妇女自 身经历的记录，讨论针对女犯人落实孕妇，哺乳的社会服务的可能性和困难。本文的研究方法是定性研究法。基 于内容分析，在访谈中收集材料和撰写田野日记。我们把女性在监狱内外的经历问题化，涉及到做母亲问题、与 孩子一起共同生活的问题、国家援助的缺失和监禁后果。因怀孕而被保释或软禁的女犯人的报告表明，尽管分婏 过程中仍然存在困难，但她们都享有充分的产前护理，产后新生儿的保育等社会福利。我们认为，给予怀孕和哺 乳的女犯人监外限制自由的做法，可以使她们更好地获得健康，有助于实现她们作为母亲的人权。能够照顾子亥子 和与家人一起生活被女犯人认为是一个令其满意的决定因素。然而，由于国家保护不足或缺之，针对怀孕或哺乳 的女犯人的制度性暴力仍然持续存在。

关键词: 女性；产妇；监狱；家庭监狱；收监听证会。

\begin{abstract}
Eu gostei da juíza, achei ela humana. A promotora, não. A promotora queria que eu ficasse presa, vendo com a barriga desse tamanho. Tudo bem, eu errei, mas poxa, tem uma criança na minha barriga, sabe? O policial foi agressivo comigo. Inclusive ele tá ali. Eles me arrastaram no chão, eu grávida. Ele machucou meu joelho. E eu tô até falando agora para ele escutar. Ele, aquele ali. Ele me jogou no chão, eu caí e bati o joelho no chão. Até hoje eu tenho problema no joelho por causa dele. E eu estava com dinheiro. Eu furtei coisa de criança, que era pro neném: xampu, sabonete, talco, Hipoglós, mas eu tinha $R \$ 150,00$ na minha bolsa, que era para mim gastar com outra coisa. Mas eu falei, não precisa me prender; eu pago o que eu peguei. E ele não quis. Tão pouca coisa, tão pouca coisa... Assim, se fosse somar ia dar uns 60 reais, por aí, 70. E ele queria, preferiu me levar presa, e eu oferecendo o dinheiro pra pagar. Então eu acho que foi covardia, por eu estar grávida. Eu errei, mas eles também foram covardes comigo. Se eu não tivesse grávida, eu ia ficar presa. Eu ia ficar presa sim (Entrevistada Darlene, 2017).
\end{abstract}

Ao longo dos últimos anos, o exercício do direito à maternidade para mulheres privadas de liberdade tem sido um tema inquietante, com produção de normas (BRASIL, 2016a, 2016b) e inovações jurisprudenciais (BRASIL, 2018b). Diversas violações a direitos humanos nas prisões atingem estas mães e gestantes, repercutindo seriamente nos seus filhos. Deste modo, ditames nacionais e internacionais apontam que deve ser priorizada a aplicação de medidas alternativas ao encarceramento, permitindo o cumprimento das determinações judiciais, simultaneamente com a vivência da relação materna e infantil.

Este artigo destaca as falas de mulheres que passaram por audiências de custódia e responderam ao processo criminal em liberdade, ilustrando as respostas institucionais 
com experiências de pré-natal, parto e cuidados pós-parto fora do ambiente prisional. $\mathrm{O}$ objetivo principal foi documentar, de forma inédita, as possibilidades e dificuldades da aplicação de medidas desencarceradoras, a partir dos depoimentos das próprias gestantes beneficiadas.

Do ponto de vista teórico-metodológico, seguimos o alerta de Favret-Saada (2005, p. 157) quando descreve a possibilidade de o pesquisador "ser afetado" no decorrer da pesquisa, na tentativa de romper "a grande divisão entre 'eles' e 'nós”. Sem negar a "intensidade afetiva" que acompanha a realidade pesquisada, o desenho metodológico construído privilegiou os registros históricos da questão da maternidade nas narrativas das mulheres. Aceitar ser afetado também supõe assumir "o risco de ver seu projeto de conhecimento se desfazer" (FAVRET-SAADA, 2005, p. 160), no sentido de não estar preso a amarras epistemológicas. Nessa perspectiva, pautados na alteridade, ouvimos as falas das mulheres grávidas e lactantes acerca do sistema punitivo, buscando desfazer e refazer valores e práticas.

A seleção das possíveis participantes da pesquisa baseou-se no banco de dados das audiências de custódia no estado do Rio de Janeiro, sistematizado pela Defensoria Pública, com registro de gestantes presas no período de 18/09/2015 até 17/03/2017. A análise de conteúdo foi organizada a partir de modalidades temáticas, com exploração do material coletado e diário de campo, produzindo-se uma síntese interpretativa que dialogou com os objetivos e questões da investigação (BARDIN, 2009).

Inicialmente, refletimos acerca de alguns obstáculos enfrentados na realização das entrevistas, problematizando especificidades da pesquisa empírica no contexto deste estudo. Em seguida, apresentamos as falas das mulheres, observando o exercício da maternidade, a convivência com o filho, a desassistência estatal e consequências do aprisionamento. Ao final, resgatamos os principais aspectos destacados ao longo do texto, de maneira crítica propositiva.

\section{Obstáculos epistemológicos da pesquisa no campo criminal}

Inúmeras limitações foram encontradas para a realização de entrevistas, principalmente dificuldades materiais que impulsionam as mães para a garantia do seu sustento ou as necessidades de cuidado dos seus filhos recém-nascidos. Conceder uma 
entrevista implica em tempo não laboral, além de custos, o que dificulta a participação destas mulheres.

Outro aspecto relevante é que este grupo de pessoas, que respondem ao processo penal fora da prisão, se encontra disperso e por vezes não quer ser identificado para evitar preconceitos. Quando realizamos entrevistas no sistema prisional, todo o universo de possíveis participantes está situado no mesmo espaço físico facilmente identificável, no qual permanecerá por determinado período. Ainda que algumas não queiram participar, outras podem ser identificadas e convidadas a conceder entrevistas. Diferente do que ocorre quando as participantes estão em seus próprios domicílios.

Decerto que entrevistas realizadas fora do ambiente prisional tendem a garantir maior tranquilidade às entrevistadas, que não mais se encontram sujeitas ao controle institucional. Todavia, ainda persiste uma desconfiança compreensível em relação a indagações acerca dos fatos que geraram o processo criminal, comprometendo algumas chances de interlocução.

Outra limitação observada foi a dificuldade de identificar nos autos dos processos os contatos dessas mulheres. Algumas não têm telefones, ou os números não funcionam mais. Assim, as entrevistas foram em número reduzido, em função das especificidades descritas, que refletem barreiras no registro de narrativas da população egressa das prisões. Porém, as falas analisadas tiveram um conteúdo denso e valor emblemático, especialmente porque os argumentos apresentados dificilmente encontram-se documentados.

Os critérios de inclusão foram: 1) gestantes ou lactantes que estivessem respondendo a processo criminal; 2) em liberdade provisória ou prisão domiciliar; 3) assistidas pela Defensoria Pública; 4) preferencialmente, mulheres que residiam na capital do RJ. Os critérios de exclusão foram: 1) mulheres com inquéritos arquivados ou já absolvidas; 2) que se encontrassem presas no sistema penitenciário, pela ocorrência de outro delito ou descumprimento da medida determinada pelo juiz; 3) mulheres assistidas por advogado particular; 4) ou que rejeitassem o convite da entrevista.

Do total de 62 gestantes identificadas como rés nas audiências de custódia no RJ, 50 responderam ao processo em liberdade (80,6\%) (SIMAS; BATISTA; VENTURA, 2018). Em 27 processos - correspondente a $54 \%$ das que estavam fora das prisões -, não foi localizado telefone de contato ou endereço, tornando-se inviáveis as entrevistas. Em outros dois casos, houve arquivamento do processo. 
As entrevistas foram realizadas com total privacidade, no espaço físico da Defensoria ou do Fórum, em condições que garantiram o sigilo. Foram excluídos dois processos por terem acompanhamento de advogado particular e, em outros dois casos, as rés residiam em outro município ou fora estado. Restaram 17 casos em relação aos quais havia possibilidade de convidar as acusadas para entrevistas e foram constatados alguns processos, nos quais o possível contato com a acusada poderia implicar em prejuízo para a defesa, devendo-se aguardar a ocorrência das citações.

Em dois casos, as mulheres já haviam sido citadas e disponibilizaram contato telefônico válido no processo. As acusadas, por telefone, aceitaram participar das entrevistas, que foram agendadas para o dia e horário por elas indicados, a serem realizadas no Fórum. Todavia, embora estivéssemos no local combinado, as possíveis participantes não compareceram e posteriormente relataram imprevistos (necessidade de trabalho e doença do filho). Por isso optamos por vincular as entrevistas a dias de audiências, nos quais as acusadas já compareceriam ao Fórum, economizando despesas. Apesar da audiência ser um momento de tensão, que geralmente atrasa e se prolonga por toda a tarde, essa foi a única possibilidade, descoberta no campo de pesquisa. Tal estratégia nos permitiu a realização de quatro entrevistas, com três lactantes e uma gestante.

\section{Experiências das mulheres dentro e fora das prisões}

Todas as mulheres entrevistadas foram presas em flagrante quando estavam grávidas, mas conseguiram realizar o pré-natal e o parto de seus filhos fora das prisões. Sofreram acusações de delitos sem violência, porém tiveram repercussões processuais distintas.

A gravidez que fundamentou o pedido de liberdade provisória ou prisão domiciliar não foi a primeira gestação de nenhuma delas. Todas eram primárias, exceto Darlene, que disse ter sido presa quatro vezes. Sua história é emblemática para descrever o quadro de exclusão e violências sofridas ao longo da vida. Assim inicia:

Eu era viciada em crack, então eu roubava para sustentar o meu vício. Em 2009, eu fui à primeira cadeia. Em 2010 eu saí e continuei fumando crack e continuei praticando furtos, mesmo tendo uma família, com pai... Aí eu saí de novo da cadeia e continuei fumando crack e fui presa de novo. Até que na terceira vez eu saí de tornozeleira, não fumei mais crack e fiquei tranquila, comecei a trabalhar, trabalhei na Cedae. Fiquei um bom tempo tranquila sem usar drogas, mas acabei voltando. E também voltei a praticar furtos de novo. [...] Dessa vez eu fui para nunca mais voltar para a cadeia, tanto que eu não fumo mais crack, eu tenho meu filho. [...] 
Eu fui presa grávida, porque eu acabei continuando a cometer furto, mas aí não era por causa de vício, era pela sociedade mesmo.

O filho é apresentado na fala, de modo a justificar a opção por um novo modelo de vida. Interessante notar que Darlene complexifica a responsabilização por seus atos: inicialmente, a transgressão à lei penal era para sustentar o vício, mas com relação ao último furto, ela aponta para as relações sociais, subentendendo-se as desigualdades socioeconômicas.

Adriana também identificou um papel de destaque para o filho em relação à sua liberdade. Não tinha planejado a gravidez e pensou em não continuar a gestação, "mas por ele que eu fui solta, né? Se eu não tivesse nenhum ...". Podemos complementar: sua situação no sistema carcerário seria diferente.

A violência no momento da prisão esteve presente em todas as falas. Mesmo tomando conhecimento da gravidez, os policiais não mudaram sua conduta violenta. Segundo Adriana, "eles nem ligaram, não tinha prova que eu estava grávida, não fizeram nada, pensaram que eu tava falando aquilo pra não ser presa". No trecho inicial deste artigo, a citação de Darlene também denuncia as agressões que sofreu no momento de sua apreensão pelo segurança, analisando a atuação do Sistema de Justiça diante de sua evidente gestação. O Ministério Público apresentou a seguinte acusação contra ela:

[...] teria subtraído do estabelecimento comercial "Drogaria Pacheco" 02 unidades de sabonete líquido, 01 escova de cabelo, 01 loção hidratante, e 03 unidades de óleo. [...] a denunciada adentrou o local, colocou os bens dentro de uma bolsa que trazia consigo e dirigiu-se à saída do local, quando foi abordada já do lado de fora pelo gerente do estabelecimento. Logo após a prática delitiva, a denunciada desacatou o policial militar Glauco, no exercício de sua função, chamando-o de "safado" e "bicho". (Denúncia acusatória).

Por esses fatos, a gestante foi denunciada por furto consumado (Art. 155, CP; pena: 1 a 4 anos, reclusão e multa); e desacato (Art. 331, CP; pena: 6 meses a 2 anos, detenção e multa). Darlene reflete a respeito: "E foi só coisa de neném que eu peguei, não foi muita coisa [...]'.

Darlene não associou a violência física sofrida com danos à gestação, mas relatou que "na outra semana a minha bolsa estourou, ele nasceu de 8 meses". O menino nasceu prematuro, com sífilis e roxo, "porque minha bolsa estourou na terça 11 horas da noite e ele nasceu na quarta-feira, 15 para às 7. Eu já não tinha mais água; eu quase fui pra cesárea. Na hora de ir pra cesárea, ele saiu". 
Acerca da contaminação por sífilis, convém destacar o relato da omissão estatal na prisão anterior da acusada em Bangu 8:

A saúde é precária. Quando eu cheguei lá, em 2014, eu fiz exame de sifilis (na UPA de Bangu), aí deu positivo e todo dia diziam que eu ia me tratar. Acabou que eu fui para o Bangu 7 e não me tratei. [...] Quando eu fui para Bangu 7, eu fui chamada para fazer o preventivo e falei pro médico da sífilis. O médico é estranho, ele é ignorante, sabe? Ele falou pra mim que eu não tinha nada. Aí eu falei: mas o exame do dedinho, deu que eu tenho. Porque no meu exame de HIV deu negativo e o de sífilis deu uma interrogação, o resultado nunca apareceu. Ele foi e falou: "Você não tá com nada, você não tem nada não".

Mas eu falei: o exame deu positivo e o outro exame não tem resultado. Como é que o senhor está falando que eu não tenho nada? "Mas eu vi o seu preventivo e você não tem nada". Sífilis não é nem pelo preventivo, é pelo sangue. Preventivo é só HPV. Então eu pensei, fiquei naquela: "tenho ou não tenho?" Mas eu saí na rua, não pensei em me cuidar... ele falou que eu não tinha. Ele ainda falou assim pra mim: "Eu acho que você é doida para pegar sífilis, porque toda vez você vem aqui falando que tem e eu já falei que você não tem". Eu fiquei grávida. Eu fiz o exame e na hora deu que eu tenho sífilis.

Por isso, Darlene falou que teve consulta "de fachada" e avaliou o atendimento como "péssimo", afinal:

[...] o médico falou que eu não tinha sífilis e acabou que eu tinha sim! O exame deu que eu tinha, mas ele ainda falou que eu não tinha. Mesmo tendo, ele falou que eu não tinha, só para não ter o trabalho de me tratar. Incrível, mas é verdade [...] Médico ridículo. Acabou que eu saí da cadeia, aí esqueci do negócio de sífilis, porque eu já estava crente que eu não tinha mesmo. Porque a sífilis, não acontece

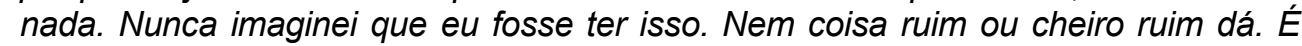
uma doença encubada. E mesmo assim, a enfermeira falou que os sintomas da sifilis é quase 15, 20 anos depois que aparece. Mas já aparece pra jogar no caixão.

A falta de assistência à saúde no sistema prisional é mais uma vez exemplificada empiricamente: "O meu marido não está conseguindo se tratar. E eu fui na Defensoria. O juiz que vai mandar um pedido para o presídio para ele se tratar. Eu tive que ir na Defensoria, porque não tem tratamento". Ainda em relação ao médico que presta atendimento no sistema penitenciário, Darlene comentou outra conduta desrespeitosa deste profissional de saúde:

Ah, sei lá, não tem como explicar não. Um homem velho daquele, com tanto erro de profissão. Ele mesmo tem que se tocar, né? Tanto tempo, porque ele já é velho, cabelo branco. Então experiência já era pra ter dado ele um tratamento melhor, saber tratar bem as pessoas, as presas. Ele é muito abusado, fala gracinha, sabe? No dia do meu preventivo, [diminui o tom de voz] sabe o que ele falou pra mim? Olha que absurdo: "Mais uma buceta larga, você tem cara de que já deu pra mais de mil homens". [Pausa. Depois volta para o tom de voz normal, mais agitado].

A coroa chegou puta na cela, porque ele falou "buceta murcha" [para a outra presa também]. A Shirlei ... Eu comentei com ela o negócio da sífilis e ela falou: "Pois é, 
ele é muito sem graça, eu quase mandei ele tomar no cu: ele falou que a minha buceta ... não né, a gente deita lá; quando ele olhou, ele falou, 'oh, buceta murcha

...”' Essa mulher já é problemática, encrenqueira, e ele ainda foi falar isso pra ela.

Diante do caos de desrespeito e desassistência naturalizados no sistema penitenciário, a garantia da liberdade provisória permitiu o tratamento de Darlene e seu filho fora dos muros prisionais. Assim ela conclui:

Ele [o filho] fez o tratamento aqui fora e não tem mais sifilis. Coisa que se fosse lá dentro, ele não ia ser tratado. [...] se não se tratar durante a gravidez a sífilis, a criança nasce com problema mental, nasce com microcefalia também, nasce cega. Meu filho é perfeito. Graças a Deus que eu pude me tratar lá fora. Me tratei durante a gravidez e depois que ele nasceu, ele ficou 10 dias com Benzetacil, ele ficou tomando Penicilina 10 dias na veia.

Por isso sua angústia diante da possibilidade de ficar presa grávida ou lactante: "Entrei em desespero por causa da sífilis, né? Eu tava me tratando, me tratei a gravidez inteira, tanto que meu filho nasceu e não tem sífilis. Eu me tratei. Ele ainda nasceu com uma manchinha [...] e agora não tem mais nada. Nem manchinha". O pré-natal foi "tranquilo", realizado na clínica de saúde da família e, quando comentou esse aspecto, Darlene comparou com o falecimento de seu primeiro filho. Mesmo tendo feito todas as consultas regularmente no pré-natal, a outra criança nasceu com rubéola, não constatada:

Diziam que meu filho era saudável, que não tinha nada, que o coração dele estava mais forte do que o meu. Acabou que o menino nasceu com sopro, cego, cheio de problemas, com rubéola - doença congênita, sem cura. Fez três meses e morreu. [...] Nem naquela morfológica, não deu; eles não viram que o menino era cego, que o menino ia ter problema de cabeça. Muito estranho.

O segundo filho recebeu todas as vacinas e, segundo Darlene, não há nenhuma preocupação com a saúde dele. Se ele ficar doente ou precisar ficar internado, a mãe busca atendimento no plano de saúde ("Memorial"), que consegue pagar com o recebimento do auxílio-reclusão do marido preso.

Adriana também fez o pré-natal todo mês, para "saber como está o bebê, se está bem. Ouvir o coração do bebê... é muito bom essa sensação". Na atual gestação, fez os exames no bebê para todos os tipos de doença, inclusive de sífilis e Aids, no posto de saúde. Com relação à gestação anterior, ela disse que não fazia pré-natal, "porque antes eu não tinha cabeça pra isso". No processo judicial de Adriana, a determinação da prisão domiciliar ficou condicionada à comprovação de consultas médicas e receituários, bem como cópias de laudos de exames. A análise documental do processo evidenciou 
declarações de comparecimento em consultas na rede pública e privada, exames de sangue e ultrassonografia.

No caso de Jaqueline, a equipe de saúde sabia que ela tinha sido presa: "Porque a agente da minha área era muito amiga nossa. Quando aconteceu isso, seria um dia de consulta. Aí ela me perguntou, porque ela sempre tava ali pegando no meu pé. Aí eu expliquei". Esta fala denota inclusive a importância do comprometimento do agente comunitário de saúde. A gestante percebeu que passaram a tratá-la diferente, "pra melhor". Não soube explicar o motivo, mas teve prioridade em quase tudo. "Eles quase não vão na sua casa. Mas quando eu tava grávida dela, depois que aconteceu isso, eles iam direto, pra saber como é que eu tava. É a clínica da Família Ana Nery". Fez muitas consultas e todos os testes, inclusive sífilis e AIDS.

Do mesmo modo, Paula fez todos os testes no bebê, nela e no companheiro também. Diz que começou a fazer o pré-natal mais tarde, logo depois que foi solta e chegou a comparecer a 8 consultas. Então, constata-se que a aplicação das medidas desencarceradoras permitiu, nestes casos, um melhor atendimento no pré-natal e pósparto para as mães e seus filhos.

Outro aspecto unânime das entrevistas foi a relevância da amamentação, com a percepção dos benefícios para a saúde do bebê e valorização na construção do vínculo materno. Darlene não precisou complementar o leite e "até os quatro meses, era só peito". Diz que amamentará "até quando ele quiser, porque eu gosto, ele gosta. É maravilhoso, é muito bom". Na gestação atual, Adriana planeja amamentar - só leite materno até os seis meses.

As entrevistadas ficaram com seus filhos no hospital; tiveram assistência médica depois do parto; os filhos encontram-se com boa saúde e sem preocupações específicas. Apresentam bom desenvolvimento e tomaram todas as vacinas. As crianças aparentam ter um desenvolvimento normal, segundo o relato das mães, com as quais brincam, vão no colo de outras pessoas, são carinhosos com os pais e irmãos. Segundo Darlene, "ele tem muito amor em casa. Quando a criança é amada, ela é boa. Ele abraça todo mundo". A expressão "é muito agarrado", utilizada por Paula, também demonstra o vínculo com os familiares.

Adriana planeja que seu parto seja normal e sua família provavelmente estará presente no hospital, mas não deverá querer acompanhar o parto. "Minha mãe não quis ver o primeiro, não sei se vai querer ver o segundo. Porque eu grito muito, porque dói demais. A dor da contração já é tanta...". A previsão é de que seja no mesmo Hospital 
Público Municipal, no qual teve sua primeira filha, por parto normal. Diz ter sido muito doloroso: "Teve uma injeção que colocaram na minha veia, porque não conseguia fazer força. Depois que me deram essa injeção, eu tive que fazer força, porque me deu uma vontade de fazer força danada". Indagada se fizeram aquele corte na vagina, a jovem diz que não, mas rasgou a mãozinha da criança e deram ponto.

Não se pode afirmar no âmbito desta pesquisa se o provável uso do medicamento ocitocina na gestante, durante o pré-parto, ocorreu de maneira justificada ou como medida de rotina não recomendável. Do mesmo modo, não se tem como inferir a imprudência com relação ao dano provocado na mão do bebê. Entretanto, é certo que a vinculação do parto a um momento de dor, sofrimento e gritos, já antecipadamente previstos, distancia aquela gestante de uma experiência reprodutiva prazerosa. Relato semelhante foi realizado por Jaqueline, que igualmente não teve uma boa experiência de parto: "Foi horrível, eu senti muita dor". Quanto ao atendimento dos profissionais de saúde, ela resume que foi "mais ou menos, porque era Natal e eles queriam comer rabanada". Deste modo, a desídia no atendimento público, não se referia ao preconceito em função da suposta prática delituosa, porque os profissionais não sabiam do seu processo criminal. Portanto, trata-se de um desrespeito corriqueiro em relação à população que se dirige ao Sistema Único de Saúde (SUS).

Jaqueline foi a única que mencionou o exercício do direito ao acompanhante na hora do parto, exercido com a indicação de sua irmã, a qual também a apoiava na Audiência de Instrução. A jovem disse que preferia a realização de cesárea; e, quando questionada se sabia que o parto normal poderia ser melhor, prontamente ela respondeu: "Não, não é melhor. Pra mim, foi horrível. O outro foi cesárea [do filho anterior], no mesmo hospital. Porque ele tava com batimento cardíaco baixo". Então, ela realmente passou pelas duas experiências distintas e a experiência do parto normal foi ruim.

O parto do filho de Paula também foi normal e, ao comparar com o dos outros filhos, ela diz que foi melhor, porque não sentiu muita dor: "me ajudaram, uma enfermeira que me ajudou, que fica na sala de parto mesmo. Me trataram bem e cuidaram muito bem dele também". Não houve queixa de nenhum tipo de violência, porém, quando questionada se teve acompanhante, ela disse que ficou sozinha, "porque não deixaram. [Falaram] Que eu era de maior e ninguém podia ficar comigo. Também porque meu parto foi normal; se fosse cesárea, podia ficar duas noites comigo. Normal não podia". A garantia legal do direito ao acompanhante não está condicionada ao tipo de parto, de 
maneira que a estipulação de critérios arbitrários não condiz com o determinado universalmente na Lei Orgânica do SUS. ${ }^{1}$ A jovem ainda ficou 10 dias internada, porque o bebê nasceu com pouco peso.

Nos três partos realizados, mesmo que tenham ocorrido sem as amarras da prisão, as mulheres que respondem ao processo em liberdade narraram aspectos da responsabilização estatal que devem ser problematizados. Vivenciaram situações de injustiça no acesso à saúde, ainda que em menor escala quando comparadas com as que se encontram encarceradas. Decerto que o parto fora do sistema prisional representa uma situação melhor, de maior tranquilidade e respeito aos direitos da mulher e seu filho. Todavia, ainda há muito a se construir para a garantia efetiva do acesso, acolhimento e qualidade na atenção ao parto de mulheres negras e pobres, em situação de acentuada vulnerabilidade social.

\section{(Ausência de) Respostas estatais}

Todas as entrevistadas tiveram algum envolvimento com drogas, mas disseram não usar mais nenhum tipo de substância, exceto Darlene, que fez referência à maconha. Quando indagada a respeito, Adriana retrucou: “Deus me livre. Só vi o tempo que eu perdi com isso". Darlene mencionou que conseguiu se afastar do crack:

Graças a Deus, tem dois anos. Dia 22/11 faz 3 anos que eu fumei pela última vez. Foi no final de novembro de 2015. Nunca mais eu fumei crack. Gosto de fumar um baseadinho, mas o crack nunca mais. Olha, eu me considero até vitoriosa. A minha mãe é a minha sina extrema. Ela me ofende muito ... às vezes ela fala umas coisas muito ruins pra mim, mas eu nem ligo. Antes eu ficava triste, mas eu nem ligo mais. Porque eu chegar a 36 anos, sem doença nenhuma, com saúde, eu não tô tão acabada, pra quem já usou o tanto de droga que eu já usei. Eu fique quase 20 anos nas drogas, eu tô sendo uma guerreira vitoriosa, porque eu consegui largar o crack. Eu confesso que eu tenho muito medo do crack, porque é uma droga muito perigosa; é uma droga muito gostosa, muito, por isso você vê o quanto as pessoas chegam.

Eu morro de medo dessa droga, mas tem dois anos que eu tô longe. E agora eu também tenho o meu neném; antes eu não tinha nada, não pensava em nada.

Em nenhuma das entrevistas houve menção a algum atendimento ofertado no SUS, pela Rede de Atenção Psicossocial (RAPS). Embora a questão das drogas tenha sido registrada pelo Estado no processo de criminalização, não foi encarada como um problema de saúde pública, com medidas de acolhimento e inclusão social.

\footnotetext{
${ }^{1}$ Art. 19-J da Lei 8.080 (BRASIL, 1990b), combinado com o §6 do art. $8^{\circ}$, do ECA (BRASIL, 1990a).
} 
A baixa expectativa de vida, pontuada por Darlene, contrapõe-se ao destaque à figura do filho, presente igualmente nas falas das outras mulheres. Quanto aos projetos para o futuro, três entrevistadas falaram em tentar voltar a estudar, ter um trabalho para ter uma vida melhor e, assim resumiu Paula: "pra poder dar de tudo pros meus filhos. E ter minha casa sem ser alugada". As necessidades materiais prementes destas mulheres estão intrinsicamente vinculadas aos seus filhos e, apesar de contarem com certo apoio familiar (de avós, irmã e pai, por exemplo), não encontram oportunidades e uma rede de assistência estatal que facilite esse retorno aos estudos e/ou inserção no mercado de trabalho.

Sobrevivem com os filhos em função da renda do companheiro, da ajuda de familiares e, no caso de Darlene, do auxílio-reclusão. Nenhuma delas tem emprego formal e somente Patrícia trabalha uma vez por semana, fazendo faxina em uma residência. Jaqueline mora só com os filhos e recebe um "dinheiro lá dos meninos lá, que o pai dela trabalhava, como cabista de internet'. A irmã também ajuda e um tio doa a cesta básica do trabalho. Ela explica que não estuda, nem trabalha por causa dos filhos, não tendo ninguém que possa ficar com eles na parte da noite. "Minha filha está muito pequena e eu tô esperando a resposta da creche, se eu conseguir...".

Adriana vende Avon, sapatilhas e produtos no brechó, mas seu sustento vem da avó e do pai da primeira filha. Ela não mencionou a busca por um emprego nas suas expectativas e disse não ter planos para o futuro, demonstrando certa apatia, desesperança ou cansaço, após horas de espera no fórum. Adriana foi a única ainda gestante na época das entrevistas e, ao ser indagada se gostaria de trabalhar, respondeu que sim, "mas não tem como mais. Por causa que eu tô grávida e tenho outra filha". Trata-se de situação diferente da de Darlene, segundo a qual:

Estou esperando resolver esse processo, para eu poder trabalhar aqui dentro do
fórum, na DEAPS [Departamento de Administração de Pessoal], porque eu fui
selecionada para trabalhar, mas quando eles viram que eu tenho um processo, eles
pediram para eu aguardar. Resolver esse processo e quando eu resolver, eu posso
voltar lá. Porque eu fui selecionada, eu tinha passado. Então, eu tô aguardando
hoje, como é que vai ser.[... Meu plano é ter um trabalho, só isso que eu penso. Eu
falei com o juiz, que eu preciso trabalhar, porque o único lugar que tem porta aberta
pra mim, que é um emprego bom e que vai limpar meu nome é aqui no Deap.
Quando eu for em outro lugar para trabalhar, eles vão ver: já trabalhou no fórum; é
ex-presidiária, mas trabalhava no fórum. Já me disseram que isso é muito
importante; meninas que trabalham aqui. Porque limpa o nosso nome, né?

As entrevistadas sobrevivem, portanto, com filhos pequenos, em regra, sem nenhum amparo estatal. De fato, a cultura política no Brasil dá suporte a efeitos ideológicos que 
obstam a institucionalização e a profissionalização de políticas públicas eficazes, caracterizando verdadeiro fracasso no atendimento a crianças no Brasil, ao longo de séculos, seja no campo assistencial, judicial, policial ou educacional (NEDER; CERQUEIRA FILHO, 2001, p.115). Quando questionadas a respeito do Bolsa Família, por exemplo, as mulheres relataram dificuldades burocráticas operacionais, como na fala de Jaqueline:

Eu fui lá já umas 500 vezes pra tentar fazer. Só que de todas as vezes que eu ia, só na última eu consegui fazer. [...] No caso, são três meses pra receber. Eu voltei lá de novo pra saber o que tinha acontecido. A moça disse que alguma coisa minha lá não tinha ido direito; meu CPF, se não me engano. Elas não colocaram corretamente, aí não deu pra fazer. Aí agora não voltei lá pra fazer tudo de novo, porque quando eu fui tava sem documento.

Paula também expôs que tentou se inscrever, mas teve problemas com seu CPF, tendo sido comunicada: "lá deu como se eu já tinha tirado; e eu nunca tirei CPF. Vou ter que ir lá na Receita Federal - eu acho -, pra poder resolver isso. [...] Aí eu não consegui". Assim, um instrumento de assistência - com inúmeras propagandas governamentais -, que deveria minimizar as mazelas sociais, na prática dessas mulheres não tem sido efetivo, sugerindo, inclusive, possibilidades de fraudes. Permanece, então, o desamparo.

Somente no caso de Darlene é possível visualizar uma pequena resposta estatal, ao garantir o auxílio-reclusão, que permite o sustento mínimo dela e de seu filho:

O meu marido também está preso. Quando ele foi preso, eu estava com 1 mês de gravidez. Ele tá lá no Hélio Gomes, em Magé; já vai fazer 2 anos, em dezembro. Tem [perspectiva de sair] em 2019. Eu me sustento assim... porque eu tô doida para procurar um trabalho. Eu tô por conta desse processo para poder trabalhar aqui na DEAP, porque fora daqui eu acredito que não vou arrumar emprego fácil. Eu tenho uma bagagem bem suja, bem pesada. Então... e arrumar creche pra ele. O meu sustento é porque meu marido trabalhou de carteira assinada, então eu tenho direito a pegar um salário, eu recebo auxílio-reclusão, que é o dinheiro que eu pago o plano de saúde dele, com tudo dele, as coisinhas dele. Mas eu quero, preciso muito trabalhar... nossa!

Mora eu, minha mãe e meu filho, no momento. Minha mãe é enfermeira do Estado. Tem 3 meses que ela não tem salário. Sério. Aí ela faz plantões extras. Ela está pagando as contas não é com o salário que tinha que ser dela, não. Ela está pagando porque ela está fazendo o bico dela. [...] Hoje mesmo ela falou que vai trabalhar pra pagar a conta de luz lá de casa; tadinha. E eu pego o auxílio reclusão, que é um salário por mês; que é o que tá me sustentando agora.

A concessão do benefício previdenciário está prevista constitucionalmente para as famílias dos presos que possuíam vínculo formal de trabalho. São pouquíssimos os familiares que conseguem obter esse direito, não só pelo desemprego estrutural que afasta milhares de trabalhadores do mercado formal, mas também em função das 
dificuldades burocráticas impostas. ${ }^{2}$ Em meio a essa situação de reiteração de exclusões, ainda existe um discurso conservador autoritário de que seria uma concessão de "privilégio para bandidos". Porém o auxílio-reclusão é um direito previdenciário fruto de contribuições prévias, com base em regras de um seguro social. Portanto, não tem natureza de benesse, doação ou favor. Mas de respeito à dignidade e às regras jurídicas fixadas anteriormente. No caso de Darlene, que reside com a mãe - com salários atrasados pelo poder público -, tendo dificuldades de obter vínculos de trabalho, o auxílioreclusão representa a forma de sua sobrevivência e de seu filho, com 1 ano e 4 meses.

A realidade de Darlene com o marido preso é a mesma de outras mulheres. O pai da filha de Jaqueline conheceu a menina nos cinco minutos da audiência, na frente de todos os profissionais (juiz, promotora, defensor, guardas e outros) que assistiam mais um ato processual. Sem muita conviç̧ão, o defensor solicitou ao juiz que o rapaz pudesse ficar alguns instantes com a filha, mas foi prontamente negado pelo representante estatal, sob a justificativa de que não era o espaço de visitas.

Diferente das demais entrevistadas, Darlene relatou ainda estar vinculada a uma instituição religiosa:

Eu tenho uma ONG que me ajuda, lá da Barra da Tijuca. Da Igreja São Vicente de
Pádua. Conhece? Ali na passarela da Barra. Então, eu pego cesta básica lá,
ganho fralda, ganho leite. Já levei meus documentos, porque eles vão me ajudar a
fazer o curso de esteticista, porque eu gosto, eu levo jeito. Sei até fazer algumas
coisas. Eles me perguntaram o que eu gostaria de fazer e eu disse: esteticista e
manicure. Aí eles vão conseguir para mim terminar o segundo grau, o curso de
esteticista e manicure. Agora estou esperando; eu já fui em 4 reuniões. Vou
passar no médico, fazer meu tratamento de dente, vou me tratar da sífilis lá.

Porque na Clínica de Saúde não dava, a minha sífilis voltou. Na Clínica da Família, eles não querem me dar mais Benzetacil, porque não está me curando mais. Eu me curei e fui transar com meu marido, ele ainda estava, a camisinha estourou, a camisinha saiu de dentro, nem estourou, saiu de dentro. Eu fui fazer e de novo peguei. Eu já tomei duas sessões de Benzetacil e continua dando reativo. E lá não tem o tratamento, só tem a Benzetacil, que é um tratamento eficaz, mas chega uma hora que tem que se tratar de outra forma. Então eles [a ONG] já estão conseguindo pra mim lá no Hemorio, para eu me tratar. A minha tutora, que cuida de mim, ela já está vendo isso. É católica. Eu sou evangélica, mas [a tutora] é minha responsável. Ela que é encarregada de mim e de mais algumas meninas; de conseguir curso, pra mim... o que eu tiver precisando tem que ser com ela que eu vou procurar. Ela está vendo médico. Ela falou: 'Você tem sorte, porque eu tenho uma amiga que trabalha no Hemorio, então eu vou levar...'.

\footnotetext{
${ }^{2}$ É muito escasso também o número de familiares das mulheres presas que recebem auxílio-reclusão. Em junho de 2016, apenas 3\% das mulheres privadas de liberdade acessavam o benefício de auxílio-reclusão. Em todo o Brasil, 14 estados indicavam 0\% de concessão (BRASIL, 2018a).
} 
A falta de assistência estatal é suprida (ao menos no discurso) pelo amparo de uma organização religiosa, ainda que diversa da professada pela beneficiada, diante das necessidades de pessoas em situações de extrema vulnerabilidade socioeconômica. É o caminho de um amigo que pode facilitar a marcação de uma consulta médica ou odontológica; é a esperança em terminar os estudos e ter um encaminhamento profissionalizante; é o desejo de conseguir um emprego. Mas todos esses sonhos estão fora da rede oficial de assistência, que se mostra distante e ineficaz para atender às demandas de saúde e sobrevivência. A conduta de Darlene evidencia uma mulher com iniciativa, buscando caminhos de integração social, porém, de concreto, só diz ter recebido doações religiosas de cestas básicas. Ela percebe os malefícios do crack e tenta se distanciar dessa realidade, mas não falou de nenhum programa de apoio recebido. Ela mencionou a necessidade de uma creche e a dificuldade de inserção no mercado formal de trabalho. Ela demonstrou responsabilidade em cuidar da saúde de seu filho, inclusive se dispondo a pagar um plano de saúde particular, mesmo diante da extrema carência financeira. Talvez o peso da perda do primeiro filho, sem maiores esclarecimentos da rede pública de saúde aos familiares, produza essa resiliência ou resistência. Enfim, consegue sobreviver nessa luta cotidiana, ainda que não receba o devido respeito aos seus direitos básicos.

No meio da entrevista com Darlene, foi feito o pregão no corredor do fórum, chamando seu nome para a audiência; e ela se dirigiu à entrevistadora: "Fica me esperando. Eles não vão me prender, vão?"

\section{Consequências do aprisionamento}

Darlene havia utilizado tornozeleira eletrônica em outra circunstância e explicou que mesmo já tendo cumprido seu livramento condicional, só retiraram o aparelho cinco meses depois. A partir de sua experiência, ela apresentou algumas regras de encaminhamento das gestantes no sistema penitenciário fluminense, comentando casos de desassistência:

A gente vai pro Talavera Bruce. Antes ficava lá no presídio até a bolsa estourar; agora não, porque teve mulheres que já chegaram a perder o filho e não dar tempo. Teve problemas lá, inclusive já foi até presa que fez parto. Lá dentro tem criança que nasceu dentro da cela e a presa fez o parto. Então agora, quando começa a crescer, se chegou presa, deu positivo, vai direto pro Talavera Bruce. 
Ao ser indagada se as grávidas sofrem na unidade materno infantil para onde são encaminhadas, inicialmente Darlene respondeu que não. Depois complementou: "eu acho que o que vai sofrer é por estar grávida, o emocional: saudade, preocupação. Aquelas que não têm com quem deixar a criança depois de 6 meses, eu já vi amigas perder criança e ir para a adoção". E então, lembrou de um caso que presenciou, fazendo referência a uma cantora Gospel, conhecida por ter adotado aproximadamente 50 crianças:

Ela adota as filhas das presas. Ela cuida da criança. Eu sei o que as meninas mesmo me falaram. Uma menina que quase perdeu pra ela, mas ela tinha um velho na rua que pegou a criança pra cuidar. Ela adota e diz que ela luta pra ficar com a criança; mesmo se a presa sair, ela não devolve. [...] Ela entra até na justiça pra ficar com a criança e muitas vezes ela consegue. Ela é cantora, ela é famosa, é uma mulher de Deus. Às vezes a criança fica até melhor com ela do que com algumas mães; eu acho, porque tem mãe viciada em crack. Eu também era usuária em crack. Mas tem gente que usa crack e é diferente. Essas que ficam na rua, na rua [repete], que mora na rua. Então dá os 6 meses e não tem quem pega a criança, a justiça toma. [...] E sempre tem familia querendo adotar, sempre.

Todas estas informações que Darlene adquiriu em relação ao encarceramento de gestantes vieram de outras presas, e não institucionalmente. Em contraposição à sua experiência, as outras entrevistadas não conheciam as regras da prisão e utilizaram voluntariamente o adjetivo "péssima" para caracterizar a experiência vivida. Assim expressaram Jaqueline e Adriana: "O pior dia da minha vida"; "era só sofrimento; muito ruim. Não sei explicar... Imagina você privada, com um filho lá fora e com um na barriga, você fica meio pra baixo, você não consegue fazer nada. Só pensar no filho".

Dentre os relatos de violência, Paula comentou: "Foi horrível. Os policiais me algemaram, me colocaram dentro daquele quartinho presa, tudo escuro. Eu fiquei com fome, fiquei com sede. Sei lá, sei nem explicar, porque nunca passou pela minha cabeça que eu ia ser presa um dia. Então foi horrível!' Embora tenha informado que estava grávida, só mudaram o tratamento no fórum: "era pra ser um lanche para cada um, veio dois. Passaram a me dar água direitinho, mandaram eu ficar calma".

Quando indagadas se houve algum esclarecimento a respeito do procedimento judicial ou da possibilidade de voltarem para o cárcere, todas responderam que nada foi explicado a respeito, nem com relação à hipótese de possível separação do filho. As liberdades provisórias foram concedidas sem maiores esclarecimentos ou encaminhamentos.

[Paula, por exemplo, narrou que no dia em que foi presa,] teve só uma moça, que não sei se ela é advogada. Lá na hora me chamou, fiquei conversando, que era pra 
eu falar a verdade pra ela, que ela ia me ajudar. Aí foi que eu falei a verdade: que eu não tinha nada a ver, porque eu fui pra loja, mas não sabendo o que eles iam fazer.

Observa-se que não são esclarecidos sequer os personagens envolvidos no cenário acusatório. A acusada não tinha certeza nem com quem ela estava falando, inclusive contando informações pessoais, na hora de uma audiência criminal.

Quanto à percepção acerca da justiça, Paula foi enfática: "Pra mim, uma criança não nasceria na prisão". E justificou:

\begin{abstract}
Eu acho que é muito complicado; é muito triste para uma criança nascer dentro de uma prisão. Quando aquela criança crescer, os amiguinhos dele deve perguntar: "onde que tu nasceu?" Aí ele vai virar e falar, nasci dentro de uma prisão. Eu acho que é muito difícil, entendeu? A gente fala assim pra uma outra pessoa: "O meu filho nasceu em uma prisão". Uma criança falar pro coleguinha dele: "Eu nasci dentro de uma cadeia, por causa de que minha mãe tava presa". Aí já vai perguntar: "O que que ela fez?" Aí a criança fica com vergonha. Então eu acho que não devia nascer dentro de uma prisão.
\end{abstract}

A vergonha e o medo do preconceito foram vivenciados por Paula, que demorou alguns meses para contar sua prisão aos familiares. Com relação aos filhos mais velhos, ela relatou seu receio:

Eu fiquei com medo deles ficarem com raiva de mim. Ele só falou: "Mãe, você não vai mais fazer isso não, para não ser presa de novo, te amo muito, eu não quero ficar longe da senhora”. Aí me pediu benção, quando cheguei lá, que ele sempre me pede. Mas graças a Deus não mudou não.

Diante dos inúmeros danos causados pela prisão, inclusive com a produção de estigmas, Paula recomendou: "Acho que eles tinham que dar oportunidade, né? Para as mulheres que têm filhos ficar cuidando dos filhos em casa, mesmo que seja em prisão domiciliar".

No mesmo sentido, Jaqueline questionou a regra de que mulheres com o filho na prisão, depois de seis meses, têm que entregar a criança a um familiar próximo ou, se não tiver, tem que ir para um abrigo:

Eu acho isso errado, porque é errado. Isso não existe. Por mais que a pessoa erre, ela tem o direito de ter outra chance. Eu acho que tem que ficar com a mãe. Porque toda criança precisa da mãe; porque mãe é mãe. Mãe pode ser o que for: ruim, boa, mas é mãe.

Darlene apresentou uma percepção de justiça, na qual problematiza a seletividade penal e atribuiu o critério da gravidade do delito para o encarceramento, com ênfase no abuso sexual ou violência contra a criança. Repara-se que o foco da sua observação foi a criança, mas também considerou a mulher: 


\begin{abstract}
Olha só, vou explicar pra você: a mulher do Cabral foi pra rua, para cuidar dos filhos, né? E tem muitas mães que têm criança pequena pra cuidar e que fica presa, às vezes por crimes muito menores, que não tem necessidade de ficar presa. [Se] Eu matei uma mulher, estrangulei uma mulher à toa: eu acho que mesmo se é mãe, eu acho que não tem que ficar na rua não, né? Agora, se é um crime bobo, assim que nem o meu, um roubozinho de farmácia, ou até mesmo um tráfico de drogas, assim. $E u$ acho que não teria necessidade de manter a mãe presa não, pela criança. $E$ pela mãe também, pelo sentimento. A separação não prejudica a mãe não; prejudica a criança. A criança sente falta da mãe. Uma hora que eu fico longe desse menino, ele chora, ele grita. Tu imagina, se eu for presa, como é que essa criança vai ficar? Mesmo tendo todo amor da minha mãe, porque a minha mãe é uma babação só; não é a mesma coisa. Então eu acho que deveria olhar pelo menos os crimes. Eu acho que um assassinato, uma covardia, um abuso sexual - a mãe que abusa sexual do filho, deixa o marido abusar - eu acho que não, isso não significa... como posso dizer, não é justificativa. Tem filho pequeno, então tem que ser solta: eu acho que para esses crimes não. Mas eu acho que um furtozinho, essas meninas que vendem droga, não faz mal pra vida de ninguém. Que nem o furto que eu fiz. Eu não sou uma pessoa perigosa. Eu?! Na época o que eu pensava assim: eu não roubo os outros, eu tiro da loja, eu tiro de quem tem milhões. Se eu achar seu celular, eu vou te devolver, não vou levar seu celular. Mas o meu problema é que eu entrava em loja, pegava as coisas pra revender. Eu... mas eu não mato ninguém, não agrido, não bato, não vou fazer mal pra ninguém. Então, pessoas com a índole assim minha, mesmo que faz coisa criminal, como tráfico... não precisava ficar presa, podia cuidar da criança em casa.
\end{abstract}

Por fim, ao serem indagadas a respeito de um possível retorno à prisão pelos fatos em relação aos quais são acusadas, nenhuma delas soube avaliar as probabilidades de condenação e as formas de cumprimento de uma possível sanção. Mostraram-se inseguras, diante dos fatos e da ausência ou insuficiência de assistência. Assim, ao ser indagada como será se tiver que voltar para a prisão, Adriana responde: "Vô ter que voltar... Vai ser bastante constrangedor, ficar sem minha filha. Nossa... Só durmo com ela. Quando eu durmo sem ela dá até falta, fico até enrolando na cama, porque eu durmo com ela nos braços".

A história desta jovem reflete, ainda, dificuldades de acesso à justiça. Era uma gestante com fala mansa e doce, muito jovem e bonita, radiante com seu barrigão. Ao entrar na audiência, a juíza a olhou com enorme reprovação. Ela foi presa com o irmão e um "namorado/ficante". Inicialmente, ela contou que esse rapaz a telefonou para ir na casa do irmão fumar um baseado, mas "como ela estava grávida, já não fazia mais isso". Mesmo assim, foram para a casa dele, local onde havia quantidade de droga considerável e material para embalar. Quando a polícia chegou, tocaram a campainha e a própria jovem foi abrir o portão, pensando que fosse sua avó. Foi surpreendida e, quando seu irmão tentou fugir pelo muro, um policial disse que atiraria se ele não parasse. A entrevistada explicou que até conseguiria fugir, quando os policiais foram atrás do irmão, mas ficou preocupada com ele e acabou sendo presa. A droga era toda dele. 
Minutos antes da audiência, a defensora saiu para conversar com ela e perguntou se ela estava nervosa. Ela respondeu que sim, então a defensora sugeriu que ela ficasse em silêncio e ela preferiu essa opção. Os outros dois réus que estavam presos contaram uma história mirabolante, com muitas brechas. Como ela ficou muda, provavelmente seria condenada. Se falasse, poderia condenar o próprio irmão... Meses após a entrevista, foi publicada a sentença de Adriana, condenada a 10 anos de reclusão; atualmente recorre ainda em liberdade.

\section{Considerações Finais}

A prisão apresenta-se como um limite estrutural para a efetivação dos direitos humanos em sua amplitude, atingindo diretamente direitos fundamentais, como a saúde, inclusive quando se trata de direitos maternos e infantis.

A descrição metodológica detalhada dos percalços enfrentados para a identificação das mulheres que poderiam participar das entrevistas evidencia algumas limitações das pesquisas empíricas no campo criminal, que devem ser consideradas na construção de estratégias investigativas futuras. Decerto que todo o processo de estranhamento no nível prático da realização da pesquisa denota que não se trata de um campo tranquilo e previsível, mas que precisa ser historicamente registrado.

O relato das mães que obtiveram prisão domiciliar ou liberdade provisória em função da gestação demonstra experiências de realização adequada do pré-natal e pósparto, com desenvolvimento saudável das crianças, embora ainda persistam dificuldades durante o parto. Deste modo, podemos concluir que a adoção de medidas desencarceradoras permitiu o exercício do direito à convivência familiar e melhor acesso à saúde, quando comparado com as condições das grávidas nas prisões, contribuindo para a efetivação do direito humano à maternidade.

A satisfação de poder cuidar dos seus filhos e conviver com a família foi constatada como um fator positivo determinante. Todavia, persistem situações de violência institucional, diante da insuficiência ou ausência de proteção estatal. Para a redução dos danos do aprisionamento, será fundamental rompermos com o ciclo de exclusão e construirmos novos caminhos de efetiva inclusão social destas mães e seus filhos. 


\section{Referências}

BARDIN, Laurence. Análise de conteúdo. Lisboa: Edições 70, 2009.

BRASIL. Presidência da República. Secretaria-Geral. Subchefia para Assuntos Jurídicos. Lei $n^{\circ}$ 8.069, de 13 de julho de 1990. Dispõe sobre o Estatuto da Criança e do Adolescente e dá outras providências. 1990a. Disponível em: http://www.planalto.gov.br/ccivil_03/leis//8069.htm. Acesso em: 22 fev. 2021.

BRASIL. Presidência da República. Secretaria-Geral. Subchefia para Assuntos Jurídicos. Lei $n^{\circ}$ 8.080, de 19 de setembro de 1990. Dispõe sobre as condições para a promoção, proteção e recuperação da saúde, a organização e o funcionamento dos serviços correspondentes e dá outras providências. 1990b. Disponível em: http://www.planalto.gov.br/ccivil_03/leis//8080.htm. Acesso em: 22 fev. 2021.

BRASIL. Presidência da República. Secretaria-Geral. Subchefia para Assuntos Jurídicos. Lei $n^{\circ}$ 13.257, de 8 de março de 2016. Dispõe sobre as políticas públicas para a primeira infância e altera a Lei $n^{\circ}$ 8.069, de 13 de julho de 1990 (Estatuto da Criança e do Adolescente), o Decreto-Lei $n^{\circ} 3.689$, de 3 de outubro de 1941 (Código de Processo Penal), a Consolidação das Leis do Trabalho (CLT), aprovada pelo Decreto-Lei $n^{\circ} 5.452$, de $1^{\circ}$ de maio de 1943, a Lei $n^{\circ} 11.770$, de 9 de setembro de 2008, e a Lei $n^{\circ} 12.662$, de 5 de junho de 2012. 2016a. Disponível em: http://www.planalto.gov.br/ccivil_03/_ato20152018/2016/lei/l13257.htm. Acesso em: 3 mar. 2021.

BRASIL. Conselho Nacional de Justiça. Regras de Bangkok: regras das Nações Unidas para o tratamento de mulheres presas e medidas não privativas de liberdade para mulheres infratoras. Brasília: CNJ, 2016b. Série Tratados Internacionais de Direitos Humanos Disponível em: https://www.cnj.jus.br/wpcontent/uploads/2019/09/cd8bc11ffdcbc397c32eecdc40afbb74.pdf. Acesso em: 14 abr. 2021.

BRASIL. Ministério da Justiça e Segurança Pública. Departamento Penitenciário Nacional. Levantamento Nacional de Informações Penitenciárias INFOPEN Mulheres. 2. ed. Brasília: Ministério da Justiça e Segurança Pública, 2018a. Disponível em: http://antigo.depen.gov.br/DEPEN/depen/sisdepen/infopen-

mulheres/infopenmulheres_arte_07-03-18.pdf. Acesso em: 14 abr. 2021.

BRASIL. Supremo Tribunal Federal. Segunda Turma. Habeas Corpus 143.641 São Paulo. Relator: Min. Ricardo Lewandowski. 20 fev. 2018b. Disponível em: https://redir.stf.jus.br/paginadorpub/paginador.jsp?docTP=TP\&docID=748401053. Acesso em: 11 nov. 2020.

FAVRET-SAADA, Jeanne. Ser afetado. Tradução de Paula Siqueira. Cadernos de Campo (São Paulo - 1991), v. 13, n. 13, p. 155-161, 2005. https://doi.org/10.11606/issn.2316-9133.v13i13p155-161 
NEDER, Gizlene; CERQUEIRA FILHO, Gisálio. Os Filhos da Lei. Revista Brasileira de Ciências Sociais, São Paulo, v. 16, n. 45, p. 113-125, 2001. https://doi.org/10.1590/S010269092001000100006

SIMAS, Luciana; BATISTA, Vera Malaguti; VENTURA, Miriam. Mulheres, maternidade e o sistema punitivo: limites e possibilidades das audiências de custódia no estado do Rio de Janeiro. Revista Brasileira de Ciências Criminais, São Paulo, ano 26, v. 149, p. 455-489, 2018. 